\title{
In Situ Hybridization Histochemistry With Synthetic Oligonucleotides: Strategies and Methods
}

\author{
MICHAEL E. LEWIS, THOMAS G. SHERMAN AND STANLEY J. WATSON \\ Mental Health Research Institute, University of Michigan, Ann Arbor, MI 48109
}

\begin{abstract}
LEWIS. M. E.. T. G. SHERMAN AND S. J. WATSON. In situ hybridization histochemistry with synthetic oligonucleotides: Sirategies and methods. PEPTIDES 6: Suppl. 2, 75-87, 1985.-In situ hybridization histochemistry is a useful method for localizing specific mRNA and studying the regulation of gene expression in an anatomical context. Previously, classical recombinant DNA and microbiological techniques have been required to identify and nick-translate the cloned DNAs necessary for in situ hybridization experiments. These requirements can be circumvented by the use of synthetic oligonucleotides complementary to the mRNA of interest. Compared to cloned cDNA probes, oligonucleotides are easy to manufacture, penetrate tissue much more easily, can be made to correspond to a sequence at any point in a known cDNA structure, and allow for the design of more precise controls for in situ studies. We describe a number of considerations in oligonucleotide probe design, including unique probe design from cDNA sequences and mixed probe design from protein primary structure data. The issues of species specificity, G-C content, probe length, tissue-specific mRNA expression, repeated sequences, non-coding region specific probes, and gene family homologies are discussed in an in situ hybridization context. Alternative strategies for mixed probe design are also considered. Information on the synthesis, purification, and sequence confirmation of oligonucleotides is then presented, followed by methods for labeling and using these probes for in situ hybridization histochemistry. The special considerations of specificity controls are addressed, including combined in situ hybridization histochemistry and immunocytochemistry, competition studies, the use of multiple hybridization probes, Tm studies, and Northern analysis of extracted RNA. The current and future directions of research with this technique are considered, with emphasis on the need to improve quantitation in order to facilitate the study of gene expression and regulation at the single cell level.
\end{abstract} $\begin{array}{llc}\text { Northern analysis } & \text { Tm analysis Terminal deoxynucleotidyl transferase } & \text { Polynucleotide kinase } \\ \text { Opioid gene family Vasopressin mRNA Proopiomelanocortin mRNA } & \text { Alternative RNA splicing } \\ \text { Permissive opposition theory Codon frequency } & \end{array}$

OVER the last few years there has been an active and very productive fusion between cell and molecular biology and the neurosciences. In large part this cross-hybridization has sprung from our need to understand the biosynthesis and regulation of peptide hormones and transmitters. As an outgrowth of these molecular neurobiology studies, it has been possible to demonstrate the pivotal role messenger RNA (mRNA) molecules play in neuronal function, especially the regulation of neurotransmission.

The ability to study the mRNA coding for specific neuronal peptides or proteins must be carried out within a knowledge of the anatomical circuitry and physiology of the systems involved. For that reason mRNA localization and relative quantitation often need to be carried out within an anatomical context (such mRNA studies are known as in situ hybridization studies). Simply stated, in situ hybridization is the localization of specific mRNAs within cells by hybridizing (binding) to them radiolabeled (or biotinylated) segments of complementary DNA (cDNA). Traditionally, most in situ hybridization preparations involve long, biologically produced cDNA probes as ligands for localizing the $\mathrm{mRNA}$ of interest. To the non-molecular biologist interested in in situ hybridization and towards the application of the technique itself, these "cloned" cDNA preparations have some substantial disadvantages associated with their use: (1) they are often difficult to obtain from other researchers (understandably) because these clones are the result of many months or years of investigative struggle; (2) typically the cDNAs are several hundred to several thousand nucleotides in length, resulting in poor tissue penetration, even after standard labeling procedures requiring DNase treatment (nick-translation); (3) the necessity for establishing microbiological and molecular biological procedures; and (4) it is often difficult to obtain precisely the short cDNA sequence one wants, because the restriction enzyme cleavage sites may not be available.

To counter these several concerns, we have begun anatomical mRNA studies using chemically synthesized cDNA probes. These probes (i.e., oligonucleotides, or oligomers) are short, single-stranded pieces of DNA which are complementary to a designated segment of the mRNA of interest, and as such, will seek out and hybridize (bind) to that mRNA, not unlike an antibody binding to its antigen (complement). Unlike antibodies, however, these oligonucleotides can be produced by an automated DNA synthesizer ("gene machine") in a few hours and purified within 3-4 days. Oligonucleotides have several major advantages over cloned cDNAs in their application to in situ hybridization 
and to the investigator interested in doing it: (1) ease of production, (2) require only a known/published sequence, (3) penetrate tissue much more easily, (4) can be designed to correspond to a sequence at any point in a known structure, and (5) allow for controls to be more precisely defined.

In the following pages we describe some of our experiences, logic, and results associated with the use of oligonucleotide cDNA probes in in situ hybridization in endocrine and nervous tissue. This manuscript attempts to provide both the introductory strategies and logic necessary to begin the design of in situ hybridization studies and the specific methods necessary to perform them. Specifically, we describe design of probes, their synthesis and purification, radiolabelling methods, a technique for in situ hybridization, specificity controls, and finally, some future directions.

\section{DESIGN OF OLIGONUCLEOTIDE PROBES}

When confronted with the many possible alternatives in the design and synthesis of oligonucleotides for in situ hybridization, it becomes clear that many compromises must be negotiated before the optimal probe has been constructed. The wishful expectations of a long probe of unique sequence for a mRNA comprising $5 \%$ of the total RNA in an anatomically distinct region with large cells are quite frequently dashed by the realistic limitations of budget, ambiguous sequence information, RNA abundance, and cell size. Each situation is quite different, however, and the extent of these various constraints are just beginning to be understood (although budgetary constraints are clearly understood). At the outset, the investigator is in one of two very different situations: is the nucleotide sequence known for the peptide, peptide precursor, or protein of interest, or, is there full or partial protein sequence information available? The design of oligonucleotide probes for in situ hybridization within each of these situations is discussed in detail in the following sections. For more general information on the synthesis and design of oligomers for hybridizations, primer extension, gene isolation, and site-specific mutagenesis, several excellent reviews are available $[1,25]$.

\section{Oligonucleotides of Unique Sequence}

In the absence of direct nucleotide sequence information, it is seldom the case that an oligomer of unique sequence can be deduced, although an interesting exception has been recorded [63]. More commonly, probes of unique structure are obtained from cDNA or genomic clones which have either been personally sequenced or previously published. When presented (or confronted) with the long nucleotide sequence coding for the protein of interest, how does one go about designing an effective oligonucleotide which not only will hybridize to this mRNA specifically, but will hybridize in the least ambiguous manner possible? What regions of an mRNA should one try to hybridize with, and which ones should be avoided? Three principle components comprise a mRNA: (1) the $5^{\prime}$ untranslated (non-coding) region, which is a sequence of varying length on the 5 ' end of the mRNA that does not code for protein. This sequence extends to the initiation codon, which is the nucleotide triplet coding for the first (amino terminal) amino acid of the protein; (2) the coding region, which is that portion of the mRNA coding for the entire protein precursor; and (3) the $3^{\prime}$ untranslated region, which, again, is a nucleotide sequence of undetermined significance at the $3^{\prime}$ end of the mRNA not coding for protein. Poly-adenylated RNAs [poly(A)RNAs] constitute the most thoroughly investigated class of mRNAs, and as is clear from their name, contain a string of adenosine nucleotides on their 3 ' ends. What are the considerations, then, in the design of an oligonucleotide to be used to detect an RNA? The greatest consideration to be dealt with when designing an oligomer probe is that of probe specificity-what is the degree of specificity desirable and/or attainable for a particular oligomer. This situation is in great contrast to that existing for immunocytochemistry, where the degree of specificity of an antibody cannot be completely dictated in advance. In terms of probability, the specificity of a nucleotide sequence within a genome increases with probe length. A 20 nucleotide length of DNA should occur only once every one trillion nucleotides, if random. In reality, however, the genome is not random, and occurrences of common or repeated sequences exist throughout the genome. Species and tissue specificities are more important criteria in the design of oligomer probes, as are such considerations as nucleotide composition, specificity within gene families, repeated sequences within or between mRNAs, alternative RNA splicing (tissue-specific expression), and coding versus noncoding mRNA sequence probes. Each of these considerations, as they relate to in situ hybridization, will be discussed in turn.

(a) Species specificity. It can be useful to have access to a probe which is not only specific to the mRNA of interest, but which is specific to that mRNA across several species. This is especially true if several species, such as rats, mice, guinea pigs, and monkeys, are being investigated. Probes such as these allow interspecies comparisons which are difficult to make when different probes are employed. Translated (coding) regions of mRNA are more highly conserved across species lines, and regions of sequence homology are more likely to occur in these areas. It should be noted that protein sequence conservation does not imply DNA sequence homology; in fact, this is seldom the case. However, isolated stretches of extreme sequence homology usually exist where protein sequences have been conserved, and advantage can be taken of these.

(b) G-C content and probe length. The stability of any given oligonucleotide:RNA hybrid is a function of five variables: (1) length, (2) composition (\% guanosine:cytosine [G-C] pairs vs. adenosine:thymidine $[A-T]$ pairs), (3) temperature, (4) salt concentration, and (5) number of base-pair mismatches. Hybrid strength is more destabilized with increasing temperature, decreasing salt concentration, decreasing duplex length, decreasing percent $G-C$ pairing $(G-C$ pairs have 3 hydrogen bonds versus 2 for $A-T$ pairs), and increasing number of base-pair mismatches. An oligomer with a $65 \% \mathrm{G}-\mathrm{C}$ content will form a more stable duplex with its complement at any given temperature than an oligomer with equal length, yet possessing a G-C content of $55 \%$. There exists, therefore, a temperature at which the former oligomer will remain complexed and the latter oligomer will dissociate (melt) completely. The temperature at which a hybrid population is half dissociated is the $\mathrm{Tm}$ value, and is, to a certain extent, an index of stability. The same is true for short versus long probes, with long probes being more stable (see Fig. 6, and section (d) of Controls). Since temperature and salt concentration are readily variable, the elements of composition and length should be considered in oligomer design. Studies in our lab and elsewhere $[1,68]$ indicate that increases in oligomer G-C content above $50 \%$ increases hybridization efficiency. Because increases in $\mathrm{G}-\mathrm{C}$ content in oligonucleotide design are not subject to the same budgetary 
constraints as the factor of probe length, it is advantageous to aim for G-C contents in the range of 55-65\%. Where cases of serious cross-homology within gene families are confronted (see section (e)), it may be desirable to adjust the G-C content such that standard hybridization temperatures cause maximal thermal destabilization of suspected mismatches (simply put, a mismatch within a DNA:RNA hybrid essentially converts a relatively long duplex into two short duplexes, rendering it unstable at temperatures approaching the Tm of the long hybrid). Very high G-C contents should be avoided if only because the temperatures required to melt off possible moderately homologous contaminating sequences would result in tissue damage.

The question of oligonucleotide length, on the other hand, is less well characterized. DNA sequences ranging from 10-14 nucleotides in length up to several hundred nucleotides long have been successfully used in in situ hybridization studies. While it is true that longer oligomers $30-50$ bases) form more stable hybrids than their shorter counterparts, it is equally true that the shorter probes are sufficiently stable. Issues such as tissue penetration efficiency, sequence specificity, hybrid stability, cost of synthesis, and ease of purification are sources of much debate. While further studies should indicate which lengths are optimal, probe lengths from 24 to 45 nucleotides meet most requirements of stringency and specificity, and are the sizes of choice in our laboratory. In situations where interfering regions of close homology exist, maximizing probe length is advantageous.

(c) Non-translated (non-coding) region specific probes. It was mentioned above that probes specific for the more highly conserved regions found in translated (coding) portions of an mRNA between species could prove useful. A more conjectural argument can be made for probes specific for non-coding regions of mRNA if one desires to study RNAs under great translational flux. These are RNAs which during physiological or pharmacological stimulation, or during development, for example, are differentially transcribed and translated. Several studies have demonstrated that increases in translated protein products can be due either to increased number of specific mRNAs or increased ribosomal loading onto those RNAs, or both $[2,51,52]$. Preliminary evidence in our laboratory suggests that increased ribosomal loading of mRNAs during stimulation may decrease hybridization efficiency in in situ hybridization analysis, presumably due to simple blockade of RNA stretches by ribosomal complexes, resulting in underestimation of the true extent of RNA increase. Whether probes specific to non-coding regions will alleviate this problem is currently being investigated.

(d) Tissue-specific expression. Tissue specificity in this instance does not mean whether or not a gene is expressed in a certain tissue, but how a gene is expressed in that tissue. The phenomenon of alternative RNA splicing is one of the more fascinating topics in molecular biology today, and is characterized by one gene encoding two or more different mature mRNAs, each expressing different protein products. Three notable cases have been described in brain: the preprotachykinin gene encoding substance $P$ and substance $K$ mRNAs $[45,47]$, the calcitonin gene transcribing calcitonin mRNA in the thyroid and calcitonin-gene-related-peptide (CGRP) mRNA in the hypothalamus [3,27], and the growth hormone gene encoding both authentic growth hormone and a variant, shorter form displaying different biological activity $[15,35]$. In each case, the product mRNAs contain regions of homology and regions of unique sequence. necessitating (a)

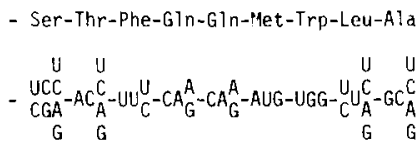

Amino acid sequence

(b) $G$

(c)

(d)

$$
A A_{G}^{A}-G T_{C}^{\top}-G T_{C}^{T}-T A C-A C C-{ }_{A} A
$$$$
\text { Mixed probe, } 16 \mathrm{seq} \text {. }
$$

$A A_{G}^{A}-G T_{C}^{\top}-G T_{C}^{T}-T A C-A C C-G A$

Codon frequency $95 \%$

(e)

$A A_{G}^{A}-G T C-G T C-T A C-A C C-G A$

Codon frequency $80 \%$

$(f)$

$A A G-G T T-G_{2} T T-T A C-A C C-r_{2} A$

Permissible opposition

FIG. 1. Design of oligonucleotide probes from an ambiguous $m R N A$ sequence (see text).

greater care in the design of oligonucleotide probes of proper specificity.

Another type of tissue-specific expression observed more frequently is the generation of multiple sized RNAs from the same gene which still code for the same protein or peptide precursor-a tissue specific heterogeneity in mRNA size of undetermined relevance. This size heterogeneity may reflect small-scale differences in RNA splicing, or heterogeneity in sites of RNA transcriptional initiation or termination (poly $A$ addition). Variations in the 5 '-ends have been well documented for several RNAs, including the 5' 100-nucleotide difference between liver and salivary gland mRNA for mouse alpha-amylase [23] and the 5' 30-nucleotide difference between porcine and rat pituitary proopiomelanocortin mRNA [50]. Tissue-specific heterogeneity in the size of rat prodynorphin mRNA has also been observed, and evidence points towards the $5^{\prime}$-end in this case also (unpublished observation, and [11]). In summary, therefore, the evidence indicates that $5^{\prime}$-ends (and suggests that 3 '-ends) of many messages can display extensive variation, and care should be taken in choosing areas within RNAs for oligonucleotide complementarity which are present in the tissue of interest.

(e) Repeated sequences and gene farmilies. Several peptides have recently been determined to be synthesized as parts of a polyprecursor. Polyprecursors contain multiple copies of the product peptide, the mature forms of which are generated by normal precursor processing. This has been observed for enkephalin [12], dynorphin [11,29], and thyrotropin releasing hormone (TRH) [17]. These multiple peptide copies, moreover, are coded for by repeated sequences of homologous or closely homologous DNAs. In bovine adrenal preproenkephalin [48], for example, an 18 nucleotide stretch encoding the lysine-extended Met-enkephalin sequence, Tyr-Gly-Gly-Phe-Met-Lys, is repeated five times at $95 \%$ homology or greater, and a further two times at more than $80 \%$ homology. Careful construction of an oligomer in these areas would provide a natural amplification of the in situ hybridization signal which would be quite advantageous were it not for the complications of cross homologies with other opioid gene products.

More common, perhaps, is the occurrence of gene families: genes which share a common evolutionary origin, probably arising through a series of partial gene duplication events. The three opioid precursors-proopiomelanocortin, proenkephalin A, and prodynorphin (proenkephalin B)-are one such gene family, as are the protein precursors for the nonapeptide hormones oxytocin and vasopressin (a small family) $[33,34]$, the tachykinins (James E. Krause, personal communication, $[45,47])$, the kallikreins $[41]$, and the kinino- 
gens [46], to name a few. These families possess extensive homologies among themselves, as a consequence of which, special care must be taken to design probes of proper specificity. For example, to avoid regions of homology between the vasopressin and oxytocin precursor mRNAs, oligonucleotides to the carboxy-terminal glycoprotein portion of the AVP mRNA, of which no complementary region exists for oxytocin, yield unambiguously specific AVP probes [60] (see Fig. 4). It is important that the phenomenon of internal DNA repeats or gene family homologies be recognized, and the affected sequences be selected or avoided consciously to avoid misinterpretation of results.

\section{Oligonucleotides of Mixed Sequence}

Much has been written about the strategies necessary for design of good mixed oligonucleotide probes when presented with a peptide or protein sequence $[1,25,67,68]$, and no attempt will be made to duplicate it all here; however, fundamental precepts will be discussed.

When confronted with a protein sequence, the object is to determine a stretch of amino acids which, when backtranslated into its ambiguous mRNA, affords the least number of redundant sequences (in other words, one wants to choose a peptide sequence that is coded for by the fewest number of DNA sequences). The problem exists because each amino acid is frequently encoded by more than one triplet codon, rendering the correct mRNA sequence for a given protein difficult to deduce. The amino acids tryptophan and methionine possess only one possible codon each, and are highly coveted; a further nine amino acidsPhe, Tyr, His, Gln, Asn, Lys, Asp, Glu, and Cys-possess only two codons each, and are similarly held in high regard. Finding a sequence of low redundancy, if one exists, within a given protein is not necessarily difficult. When backtranslated, a good oligonucleotide sequence within a protein is sometimes quite obvious. In the protein sequence illustrated in Fig. 1, for example, there is a stretch of nine amino acids which back-translate to the indicated ambiguous mRNA sequence (line b). Within this sequence a 17 nucleotide length $(17 \mathrm{mer})$ with a redundancy of $16(2 \times 2 \times 2 \times 2)$ is readily apparent, and would be a fine probe in most situations outside of in situ hybridization. Its complement is shown in line (c). One can attempt to reduce the redundancy by adopting one of two strategies, or a combination of both: codon frequency [49] or permissible opposition [1].

Codon frequency strategy allows a choice between two or more codons for an amino acid to be made if one codon is used much more frequently than the other(s). In the example illustrated in Fig. 1, there is a $90 \%$ probability in the rat that the codon for glutamine (Gln) is CAG versus CAA, and may be a reasonable gamble. On the other hand, the codon UUC for Phe is chosen only $65 \%$ of the time in rat, approximately, and would be a poor choice for an oligomer. With reasonable certainty, therefore, the redundancy of the 17 mer could be reduced to 4 by adopting CAG for Gln. Where this strategy can be more helpful, however, is in reducing the redundancy of a codon to a more manageable number. For instance, there is nearly a $95 \%$ probability in the rat that the $5^{\prime}$ nucleotide for Leu is cytosine $(C)$ rather than uridine $(\mathrm{U})$, decreasing its redundancy from 6 to 4 . This can be most useful when a very redundant codon lies in an otherwise attractive oligomer sequence. Line (d) of Fig. 1 illustrates the results of the application of the high probability codon assumption for Leu $(>95 \%)$, yielding a mixture of 8 oligomers, and line (e) shows this with the product of the two lower probability choices for Gln (>80\%), reducing the total mix to only 2 .

The strategy of permissible opposition, on the other hand, acts on the supposition that if mismatches are to occur, one should consider which mismatches are the least destabilizing to the hybrid. It has been determined that deoxyguanosine:uridine (dG-U) and deoxy-thymidine:guanosine (dT-G) pairings are less stable but allowable mismatches in the design of oligomer probes. (Note: the deoxy nomenclature is used here only to more clearly differentiate the DNA oligomer from the RNA it hybridizes with.) Thus, the "wobble" position nucleotide (the nucleotide displaying the greatest redundancy within a codon) can be designated $\mathrm{dG}$ for Phe, Tyr, His, Asn, Asp, and Cys, and dT for Gln, Lys and Glu with reasonably good success [1]. In the illustration of Fig. 1, therefore, a 17 mer unique sequence probe could be designed using permissible opposition theory (line f). This oligomer would, in fact, be less stable than the probabilistically favored sequence (by codon frequency) if the latter sequence were correct, but greatly more stable if the latter sequence were incorrect. Furthermore, the unique sequence probe would not have the background and nonspecificity difficulties inherent in working with a mixture of 16 different sequences.

SYNTHESIS AND PURIFICATION OF OLIGONUCLEOTIDE PROBES

\section{Synthesis of Oligonucleotides}

The automation of nucleotide synthesis, as the term "gene machine" conveyed in the introduction, is the culmination of thirty years of research and development. The field of synthetic nucleotide chemistry has evolved from the pioneering solution-phase phosphodiester chemistry of Khorana [32], through the development of a more stable phosphotriester chemistry, to its present day adoption of Merrifield's peptide solid-phase synthesis strategy [17] as modified for nucleotide synthesis by several groups [18, 26, 42]. The successful use of a solid phase strategy greatly extended the application of automation to nucleotide chemistry, as it had done previously for peptide synthesis. The advantages of solid phase over solution phase synthesis are threefold: (1) the growing oligonucleotide is attached to a solid matrix, thus permitting reagents and soluble byproducts to be removed by filtration, (2) an excess of reagent (activated nucleotide) can be used to drive the reaction to completion, and (3) higher oligomer yields are obtained since constant probe purification between additions is greatly simplified.

Two separate chemistries have evolved for the chemical assembly of oligonucleotides on a solid support: phosphotriester [26] and phosphoramidite [42]. The names refer to the product molecules, which are triester phosphate or phosphoramidite salts. The two chemistries differ in the time required for effective coupling, the quality and expense of reagents, and the stability of the activatable nucleoside phospho-derivatives. The oligomers described in this manuscript were prepared with phosphoramidite chemistry on an Applied Biosystems Model 380A DNA Synthesizer. More detailed information on the individual chemistries can be obtained in the indicated references $[25,26,42]$.

Several points should be considered regarding the final chemical form of the synthetic oligomer and how this relates to its eventual means of purification. When the synthesis is complete, four additional steps are necessary to yield biologically active DNA, and they each involve removal of protect- 


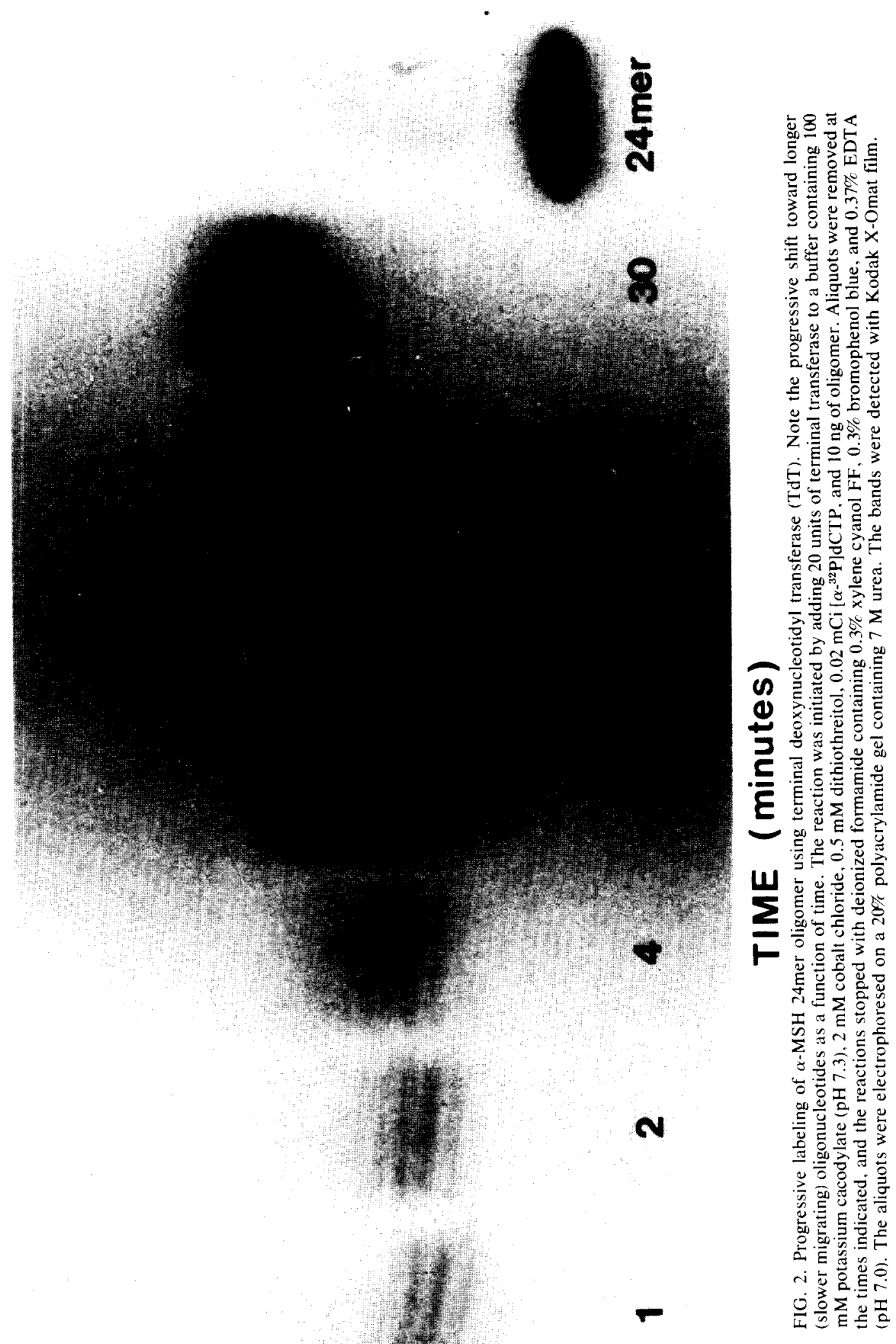



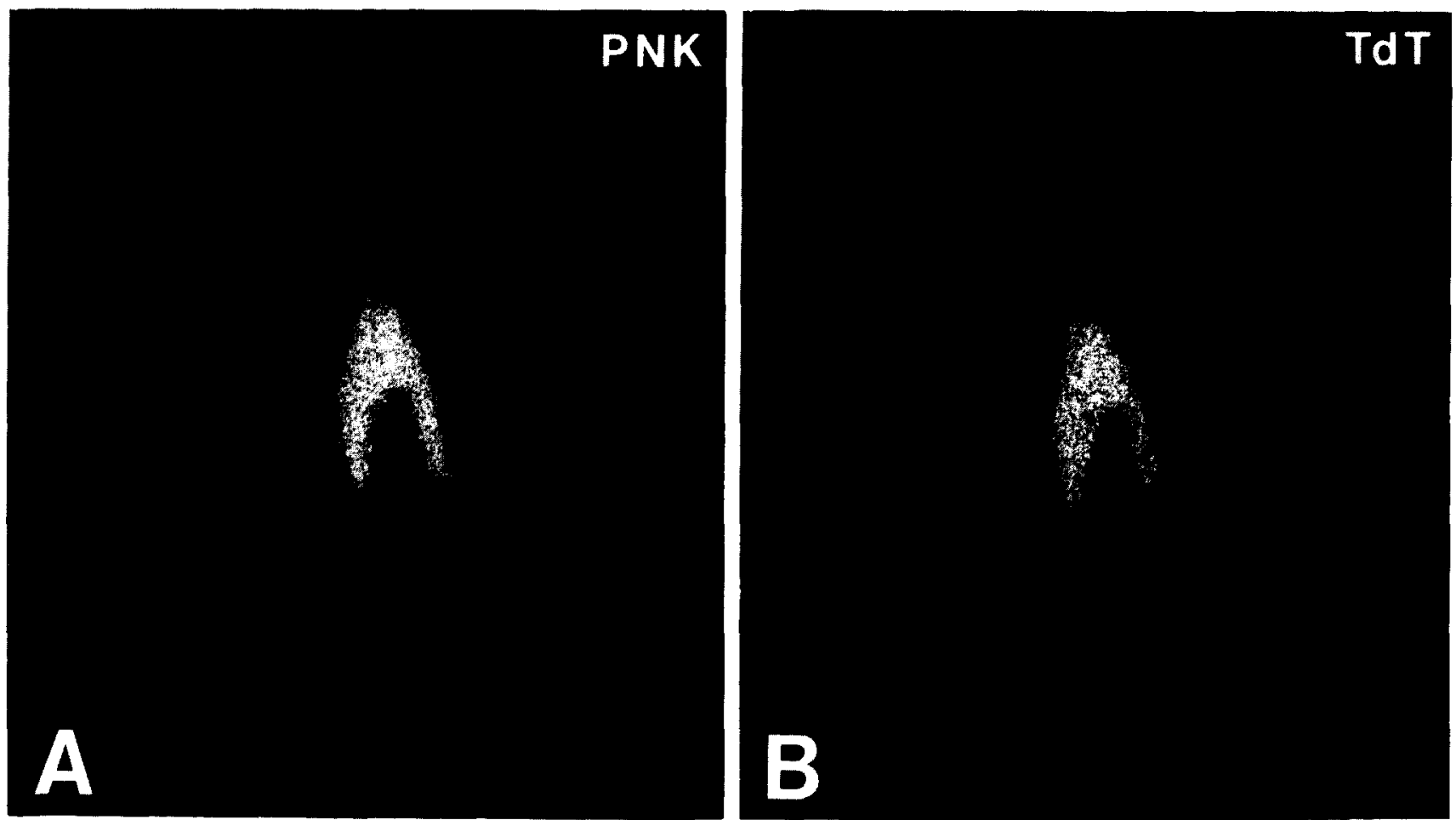

FIG. 3. In situ hybridization comparison between terminal transferase (TdT) labeled and polynucleotide kinase (PNK) labeled $\alpha$-MSH oligonucleotides. Ten micron sections of rat pituitary are probed with equivalent $\left[{ }^{32} \mathrm{PJ}\right.$ dpms of either 5 '-polynucleotide kinase labeled probe, or $3^{\prime}$-terminal deoxynucleotidyl transferase labeled probe (with an average addition of 8 cytosine monophosphates). The hybridization and wash conditions are as described in the text. The distribution of autoradiographic grains is qualitatively similar in each of the two preparations. $\mathrm{Tm}$ analysis indicates that the properties of the PNK labeled probe hybridization are essentially retained with TdT labeling.

ive blocking groups from the DNA molecule. One of these in particular, a large, hydrophobic dimethoxytrityl (DMT) group, which blocks the 5' end of the oligomer, can be very helpful in the purification of the product oligomer. If oligomer purification is to be performed by gel electrophoresis or reverse-phase HPLC (see below), an effort should be made to obtain a deprotected oligomer still containing the DMT group.

\section{Purification of Oligonacleotides}

The purification of the final product oligonucleotide involves the separation of the specific oligomer from both the many contaminating truncated oligomers and the many salts present from the deprotection procedures. The percentage of total truncated (shorter) oligomers depends on the efficiencies of each coupling reaction, but even when these coupling efficiencies are $98 \%$, only a $60 \%$ yield is obtained for a 24 mer. Two of the three more common purification schemes, gel electrophoresis and anion exchange column chromatography, select for the desired product oligomer on the basis of it containing the longest nucleotide sequence, whereas reverse-phase HPLC selects on the basis of hydrophobicity (the presence or absence of the 5' dimethoxytrityl [DMT] group). The two most general purification methods described below are condensed and/or modified from a methods publication available from Applied Biosystems, Inc.

(a) Gel electrophoresis. Prior to electrophoresis, the crude oligomer should be desalted by fractionation through a Sephadex G50-fine column. These columns are best pre- pared in $10 \mathrm{ml}$ disposable syringes or econo-columns in a buffer containing $10 \mathrm{mM}$ triethylammonium bicarbonate (TEAB), pH 7.0. A $1.0 \mathrm{M}$ stock can be easily prepared by adding dry ice to $1.0 \mathrm{M}$ triethylamine until $\mathrm{pH} 7.0$ is secured. Material absorbing at $260 \mathrm{~nm}$ will elute in the void volume. The TEAB buffer can be removed by lyophilization.

Electrophoretic separation of the oligomer products on a $20 \%$ acrylamide gel containing $7 \mathrm{M}$ urea [43] yields a truncated-oligomer ladder which can be visualized by UV shadowing. For UV shadowing, transfer the gel to plastic wrap and place on a fluorescent background (such as a TLC plate). The individual DNA bands can be illuminated by UV light. The desired DNA bands can be excised and extracted from the acrylamide by the crush-and-soak procedure [62]. A recent publication suggests that removal of the DMT protective group is not a prerequisite for electrophoretic purification [25], and may, in fact, provide for a cleaner separation of oligomer from the $\mathrm{n}-1$ truncated contaminant

(b) Reverse-phase HPLC. As opposed to electrophoretic purification, the presence of the DMT-group is required for reverse-phase chromatography. The DMT group contributes a large hydrophobic moity to the specific product oligomer which causes that oligomer to be retained on a hydrophobic affinity column ( $\mu$ Bondapak $C-18$ column, Waters Inc.; PRP-1 resin, Hamilton; Ultrasphere-ODS C-18, Altex).

Resuspend the crude oligomer in $250 \mu \mathrm{l} 10 \mathrm{mM}$ ethylenediamine, $\mathrm{pH}$ 8.0. Remove any insoluble material by centrifugation. The oligonucleotides are fractionated on a reverse-phase column using a $5-35 \%$ acetonitrile gradient over $20-30$ minutes at $1.5 \mathrm{ml} / \mathrm{min}$. The bulk of non-tritylated 
truncated oligomers will elute immediately, whereas the trityl bound product will typically elute between 15-25\% acetonitrile. The volatile buffer is removed by lyophilization, the trityl group removed as described in the previous section, and the final DNA product purified on a shallow $(0-15 \%)$ acetonitrile gradient.

\section{Confirmation of Oligonucleotide Sequence}

Sequence analysis provides the final information necessary for confirmation of both synthetic composition and length. The two most applicable methods for the sequence analysis of oligonucleotides are the wandering spot procedure [57] and the Maxam and Gilbert reactions [43,55]. The wandering spot procedure is a very sensitive sequencing protocol limited to nucleotides from 18-20 nucleotides in length. Modifications of the Maxam and Gilbert sequencing method, on the other hand, will permit analyses on any length oligomer.

\section{LABELING OF OLIGONUCLEOTIDE PROBES}

Once the oligonucleotide has been synthesized and purified, it must be labeled to permit its detection following hybridization to a complementary nucleic acid. The customary use of oligonucleotides as hybridization probes for screening colonies from cDN A libraries, or Southern (DNA) or Northern (RNA) blots, requires labeling to a high specific activity. Since these applications require high specific activity and not a high degree of resolution (i.e., only that provided by X-ray film), the probes are generally $\left[{ }^{32} \mathrm{P}\right]$-labeled on the $5^{\prime}$ hydroxyl terminus using $\mathrm{T} 4$ polynucleotide kinase with $\left[\gamma^{32} \mathrm{P}\right] \mathrm{ATP}$ as the $\left[{ }^{32} \mathrm{P}\right]$ donor $[40]$. This procedure provides labeled probes which are suitable for relatively lowresolution, high-signal screening of tissues by in situ hybridization. Since this reaction can only be used for $\left[{ }^{32} \mathrm{P}\right]-$ and $\left[{ }^{35} \mathrm{~S}\right]$-labeling [4], and we were interested in using lower energy $\beta$-emitters (e.g., $\left[{ }^{3} \mathrm{H}\right]$ ) for high resolution autoradiography, an alternate method of labeling the probes was developed. Terminal deoxynucleotidyl transferase catalyzes the polymerization of deoxynucleoside triphosphates (dNTPs) to the 3'-hydroxyl terminus of single-stranded DNA [5], a reaction used for complementary homopolymer tailing of vectors and insert sequences for DNA cloning [40]. Using this reaction, we have "tailed" oligonucleotide probes using $\left[{ }^{3} \mathrm{H}\right],\left[{ }^{35} \mathrm{~S}\right]$, or $\left[{ }^{32} \mathrm{P}\right] \mathrm{dNTPs}$, or biotinylated dUTP, for in situ hybridization histochemistry and Northern blotting [36-38]. This approach has the advantages of labeling the probes with multiple bases to enhance detection as well as permitting the use of lower energy emitters than $\left[{ }^{32} \mathrm{P}\right]$ to enhance anatomical resolution. A direct comparison of the two labeling paradigms for in situ hybridization in pituitary is illustrated in Fig. 3. Protocols for carrying out oligonucleotide labeling $[14,40]$ with commercially available reagents, are as follows:

$5^{\prime}$-Polynacleotide kinase. Dry $100-500 \mu \mathrm{Ci}\left[\gamma^{-32} \mathrm{P}\right] \mathrm{ATP}$ (New England Nuclear) in a siliconized Eppendorf tube, and add $2.5 \mu \mathrm{l} 0.1 \mathrm{M} \beta$-mercaptoethanol, $2.5 \mu \mathrm{l} 0.1 \mathrm{M} \mathrm{MgCl}_{2}$, $1.75 \mu l 1 \mathrm{M}$ Tris $\mathrm{HCl}$ ( $\mathrm{pH} 7.6$ ) and $0.5-1 \mu \mathrm{g}$ oligonucleotide in distilled $\mathrm{H}_{2} \mathrm{O}$ to yield a final volume of $10 \mu \mathrm{l}$, followed by polynucleotide kinase ( 2 units, New England Biolabs) to initiate the reaction, which is carried out at $37^{\circ} \mathrm{C}$ for 30 minutes. The reaction is stopped by addition of $5 \mu$ l stop solution (deionized formamide containing $0.3 \%$ xylene cyanol $\mathrm{FF}$, $0.3 \%$ bromophenol blue, and $0.37 \%$ disodium EDTA, $\mathrm{pH} 7.0$; New England Biolabs No. 405-4). Labeled oligomer can be purified either by gel electrophoresis as presented in the next paragraph (Fig. 2), or fractionated on a Sephadex G50 column as discussed in the oligonucleotide purification section.

3'-Terminal deoxynucleotidyl transferase. Dry labeled dNTP (e.g., $\left[\alpha-{ }^{3} \mathrm{H}\right] \mathrm{dCTP}$ New England Nuclear) in a siliconized Eppendorf tube, and add $5 \mu \mathrm{l} 5 \times$ potassium cacodylate tailing buffer (BRL) and 0.5-1 $\mu$ g oligonucleotide in distilled $\mathrm{H}_{2} \mathrm{O}$ to yield a final volume of $25 \mu \mathrm{l}$, followed by terminal deoxynucleotidyl transferase (20-25 units, BRL) to initiate the reaction which is carried out at $37^{\circ} \mathrm{C}$ for $30 \mathrm{~min}$ utes. The reaction is stopped by addition of $5 \mu \mathrm{l}$ of stop solution as before. Oligonucleotides labeled in either manner can be separated on a $20 \%$ urea gel prepared in the following manner: dissolve $10.5 \mathrm{~g}$ ultrapure urea in $12.5 \mathrm{ml} 40 \%$ acrylamide: bis-acrylamide $(39: 1)$ and $2.5 \mathrm{ml} 10 \mathrm{X}$ TBE (stock: $108 \mathrm{~g}$ Tris base, $55 \mathrm{~g}$ boric acid, and $9.3 \mathrm{~g}$ disodium EDTA in 1 liter, pH 8.3) by gentle heating, then cool and add $10 \mathrm{ml}$ sterile distilled $\mathrm{H}_{2} \mathrm{O}, 250 \mu \mathrm{l} 10 \%$ ammonium persulfate (fresh), and $25 \mu \mathrm{l}$ TEMED (Kodak No. 8178), which is mixed, immediately poured, and allowed to solidify for 1 hour before electrophoresis. When the gel has finished running, as indicated by migration of the dyes, cover the gel lying on the electrophoresis plate with saran wrap, and autoradiograph with X-ray film (see Fig. 2). Cut out the "bands" from the gel and elute overnight with shaking in an Eppendorf tube containing $500 \mu \mathrm{l}$ DNA extraction buffer $(500 \mathrm{mM}$ ammonium acetate, $10 \mathrm{mM}$ magnesium acetate, $0.1 \%$ SDS, and $1 \mathrm{mM}$ EDTA) at $37^{\circ} \mathrm{C}$. If the isotope (e.g., $\left[{ }^{3} \mathrm{H}\right]$ ) used in the terminal transferase reaction cannot be rapidly detected using X-ray film or LKB Ultrofilm, a separate "tracer" reaction can be carried out with $\left[\alpha-{ }^{32} \mathrm{P}\right] \mathrm{dNTP}$ and run in an adjacent lane in the gel.

\section{IN SITU HYBRIDIZATION HISTOCHEMISTRY}

A large number of methods for carrying out in situ hybridization histochemistry have been published $[7,19,20,21$, $22,39,53,56,61]$, with significant variations in the tissue fixation, prehybridization, hybridization, and posthybridization conditions. The development of optimal conditions for a given probe in a particular application is largely empirical, and investigators should systematically investigate these variables in their own preparations. The following method has proven useful for several probe applications in our laboratory.

If desired, rats can be pretreated with colchicine (50-250 $\mu \mathrm{g} / 10 \mu \mathrm{l}$ saline, intracerebroventricularly) $24-48$ hours prior to being anesthetized and perfused with $50 \mathrm{ml}$ ice-cold saline followed by cold $0.1 \mathrm{M}$ phosphate-buffered $4 \%$ formaldehyde for 30 minutes at $130 \mathrm{~mm} \mathrm{Hg}$ (see Watson and Akil [69] for details). Colchicine pretreatment enhances the accumulation of peptides for mRNA-peptide colocalization studies [19], and also appears to enhance the detection of mRNA under some circumstances [20]. Following perfusion, the tissue (e.g., brain, pituitary) is removed, postfixed in ice-cold buffered formaldehyde for 1 hour, followed by overnight incubation in $15 \%$ sucrose in $0.02 \mathrm{M}$ phosphate-buffered saline [69] at $4^{\circ} \mathrm{C}$, freezing in liquid nitrogen, sectioning on a cryostat $\left(10 \mu \mathrm{m}\right.$ at $\left.-20^{\circ} \mathrm{C}\right)$, and storage at $-80^{\circ} \mathrm{C}$. For prehybridization, the slides are brought to room temperature (RT), a spot of nail polish is applied near the section and allowed to dry (to facilitate later removal of the cover slip), and the slides are sequentially incubated in $95 \%$ ethanol $\left(-70^{\circ} \mathrm{C}\right.$ for $10 \mathrm{~min}$ ), $80 \%, 70 \%$, and $50 \%$ ethanol and double distilled $\mathrm{H}_{2} \mathrm{O}$ (3 minutes each), $0.2 \mathrm{~N} \mathrm{HCl}$ (RT, 20 minutes), 2X-SSC 
$(1 \times \mathrm{SSC}=0.15 \mathrm{M} \mathrm{NaCl}, 0.015 \mathrm{M}$ sodium citrate, $\mathrm{pH} 7.2)$ $\left(70^{\circ} \mathrm{C}, 30\right.$ minutes), and $2 \mathrm{X}-\mathrm{SSC}$ (RT), followed immediately by a suitable volume (e.g., $50 \mu$ l) of prehybridization buffer. A prehybridization buffer stock of $10 \mathrm{ml}$ (aliquoted and stored at $-20^{\circ} \mathrm{C}$ ) is prepared by adding $1 \mathrm{~g}$ dextran sulfate to $9.6 \mathrm{ml}$ double distilled $\mathrm{H}_{2} \mathrm{O}, 200 \mu \mathrm{l} 1 \mathrm{M}$ Na phosphate $(\mathrm{pH}$ 7.4), and $200 \mu \mathrm{l} 50 \mathrm{X}$ Denhardt's, stock for which is prepared by dissolving $5 \mathrm{~g}$ each of Ficoll, polyvinylpyrrolidone, and bovine serum albumin (Pentax fraction $V$ ) in double distilled water up to $500 \mathrm{ml}$. The tissue section is covered with prehybridization buffer (e.g., $50 \mu$ l) for 2 hours at $37^{\circ} \mathrm{C}$; for some applications, it may be necessary to modify the time and temperature of this incubation. Appropriate dilutions of the labeled probe (e.g., $250,000 \mathrm{cpm} / 50 \mu \mathrm{l}$ ) in hybridization buffer are applied to the tissue, which is then coverslipped and incubated overnight (or longer if necessary) at room temperature or warmer (e.g., $37^{\circ} \mathrm{C}$ or $45^{\circ} \mathrm{C}$ ). The concentration of probe and the length and temperature of hybridization must be optimized for each probe in a given application. Hybridization buffer stock $(10 \mathrm{ml}$, aliquotted and stored at $-20^{\circ} \mathrm{C}$ ) can be prepared by adding $1 \mathrm{~g}$ dextran sulfate to a solution containing $3.075 \mathrm{ml} \mathrm{H}_{2} \mathrm{O}, 1.5 \mathrm{ml} 20 \mathrm{X}-\mathrm{SSC}, 200 \mu \mathrm{l}$ 50X Denhardts, $100 \mu \mathrm{l}$ salmon sperm DNA $(10 \mathrm{mg} / \mathrm{ml}$ stock, sonicated), $125 \mu \mathrm{l}$ yeast tRNA $(10 \mathrm{mg} / \mathrm{ml}$ stock), and $5 \mathrm{ml}$ deionized formamide, the stock for which is prepared by mixing $50 \mathrm{ml}$ formamide and $5 \mathrm{~g}$ mixed-bed ion exchange resin (Bio-Rad AG 501-X8, 20-50 mesh), stirring for $30 \mathrm{~min}$ utes (RT), and filtering through Whatman No. 1 filter paper (store at $-20^{\circ} \mathrm{C}$ ).

For posthybridization washing, the slides are individually immersed in 2X-SSC (RT) and the coverslips are gently removed with the edge of a razor blade. Racks of slides are then washed, with stirring, in $200 \mathrm{ml}$ of $2 \mathrm{X}-\mathrm{SSC}$ ( 2 hours), $1 \mathrm{X} \mathrm{SSC} \mathrm{(1} \mathrm{hour),} \mathrm{and} \mathrm{0.5X-SSC} \mathrm{(} 1$ hour) at room temperature or warmer. To reduce background, the stringency of the washing conditions can be increased by raising the washing temperature and further reducing the concentration of SSC.

The slides are air-dried, the spot of nail polish is removed, and autoradiographic detection is carried out by exposing the slides in a cassette to X-ray film or LKB Ultrofilm (sensitive to $\left[{ }^{3} \mathrm{H}\right]$ and $\left.\left[{ }^{125} \mathrm{I}\right]\right)$, or, for higher resolution, dipping the slides in Kodak NTB2 emulsion $\left(42^{\circ} \mathrm{C}\right.$, diluted $1: 1$ in $1 \mathrm{mg} / \mathrm{ml}$ sonicated Dreft) in a darkroom with $50 \%$ humidity. The slides are permitted to dry for 2 hours in an upright position (a scintillation vial tray lined with absorbent paper is convenient), stored at $4^{\circ} \mathrm{C}$ in a lightproof slide box containing Drierite capsules, and developed after an appropriate length of time, as determined by periodic development of test slides. Development is carried out in Kodak D-19 for 2 minutes at $16^{\circ} \mathrm{C}$, followed by washing in water for 15 seconds, and fixation with Kodak Rapidfix for 3 minutes, rewashing in water for 45 minutes, dehydration through ascending concentrations of ethanol, clearing in xylene, and coverslipping in Permount for microscopic examination. Before dehydration, it may be desirable to lightly stain the tissue (e.g., with a Nissl stain).

\section{IN SITU HYBRIDIZATION SPECIFICITY CONTROLS}

In immunocytochemistry, the specificity of the antisera used is a major concern; cross-reactivity can result in misleading "false-positive" staining. Similarly, for in situ hybridization histochemistry, hybridization of the probe to noncomplementary RNA (or other forms of nonspecific binding) would yield erroneous localizations. Thus, as described below, several control procedures have been developed to ensure the specificity of the detected hybrids.

(a) Combined in situ hybridization and $\mathrm{im}^{-}$ munocytochemistry. The availability of specific antisera to peptides coded for by a particular mRNA are helpful in establishing specificity of localization. When fixation conditions are selected to preserve both peptide antigenicity and mRNA structure (as described here), correlative immunocytochemistry and in situ hybridization histochemistry can be carried out on adjacent sections [19] or even on the same section [21]. Ideally, the section processed for mRNA localization is "sandwiched" between two sections processed for peptide immunocytochemistry, using either the same antiserum or antisera directed against different peptides from the same precursor coded for by the mRNA (see [69] for further discussion). When processing a single section for both histochemical procedures, PAP immunocytochemistry is carried out [69], followed by in situ hybridization and emulsion-dipping (described before): autoradiographic grains and HRP reaction product are then simultaneously detected using darkfield or brightfield microscopy.

(b) Competition studies. Competition studies can be carried out by using saturating concentrations of unlabeled oligonucleotide (cDNA). This unlabeled cDNA probe can be hybridized to the mRNA in the tissue section before application of the labeled probe. Since there is a small concentration of mRNA relative to potential "nonspecific hybridization" sites, only the specific hybridization signal should be attenuated. This has been demonstrated in our laboratory for an $\alpha$-MSH probe hybridizing to pituitary intermediate lobe. There has been some discussion of a second type of competition study to be carried out by preincubating the labeled probe with an mRNA sense (i.e.. complementary) oligonucleotide prior to the in situ application of the probe. While it may seem reasonable to use a message sense DNA probe to saturate the labeled cDNA probe in solution, in fact, the results are misleading. This procedure would appear to be analogous to a peptide blocking its $\operatorname{IgG}$ in an immunocytochemical study, but, unfortunately, this common impression is erroneous. The difference is that the oligonucleotide solution contains only a single molecular species, and it is clear that an excess of message sense DNA will enable complete hybridization with the cDNA and render it unavailable for tissue binding. In fact, having run such studies, we have observed a reduction of both specific and non-specific signals. In effect, this procedure is not a specificity control at all but merely demonstrates the law of mass action (e.g.

\section{FACING PAGE}

FIG. 4. In situ hybridization detection of magnocellular AVP mRNA. Twenty-four hour X-ray film exposures of $5^{\prime}$-[32P]-labeled oligonucleotide hybridizations with rat hypothalamic 10 micron formaldehyde fixed frozen sections; negative print. Frame A: Approximately $4 \times 10^{5}$ dpms of 5'-kinased AVP II oligomer ( $10 \mathrm{ng}, 26 \mathrm{mer}$ ) are hybridized as described in the text. A section through the paraventricular nucleus (PVN) of hypothalamus exhibited a positive signal corresponding with the PVN (arrows). Frame B: Approximately $5 \times 10^{5} \mathrm{dpms}$ of 5 '-kinased AVP I oligomer (10 ng, 20mer) are hybridized as described in text. A section through rostral hypothalamus displayed a positive signal over the supraoptic nuclei (SON). Background grains, showing tissue boundaries, are eliminated by washing in $0.5 \mathrm{X}-\mathrm{SSC}$ at $45^{\circ} \mathrm{C}$ for $1 \mathrm{hr}$. 


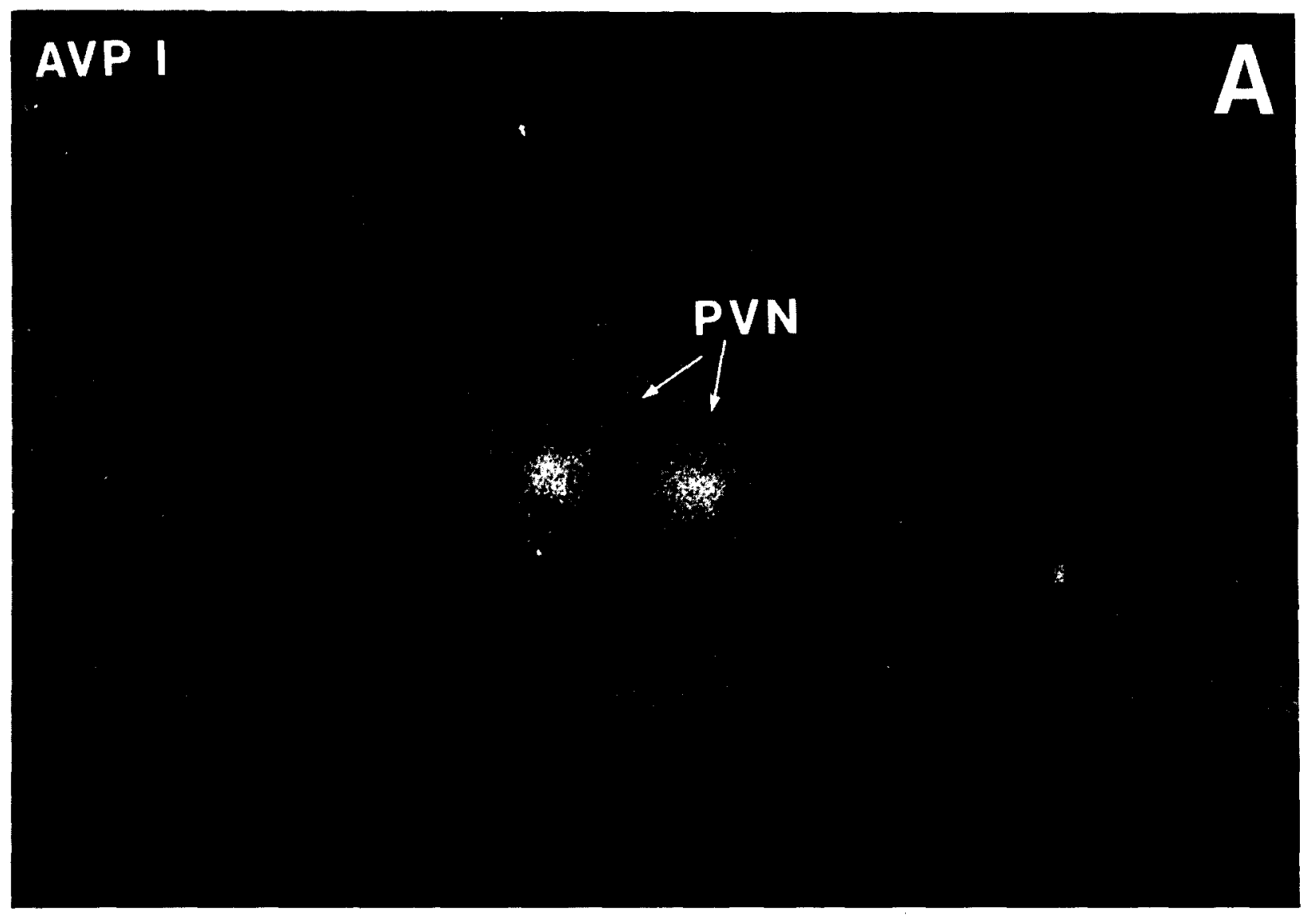

\section{AVP II}

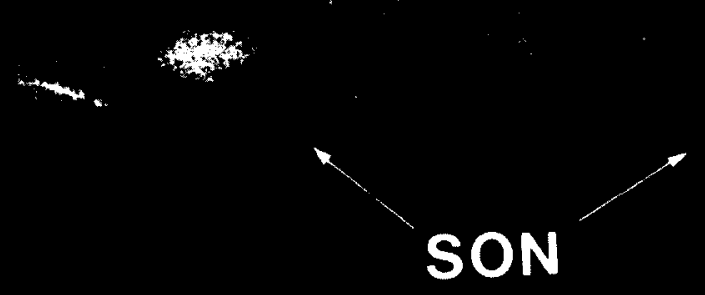

诲 


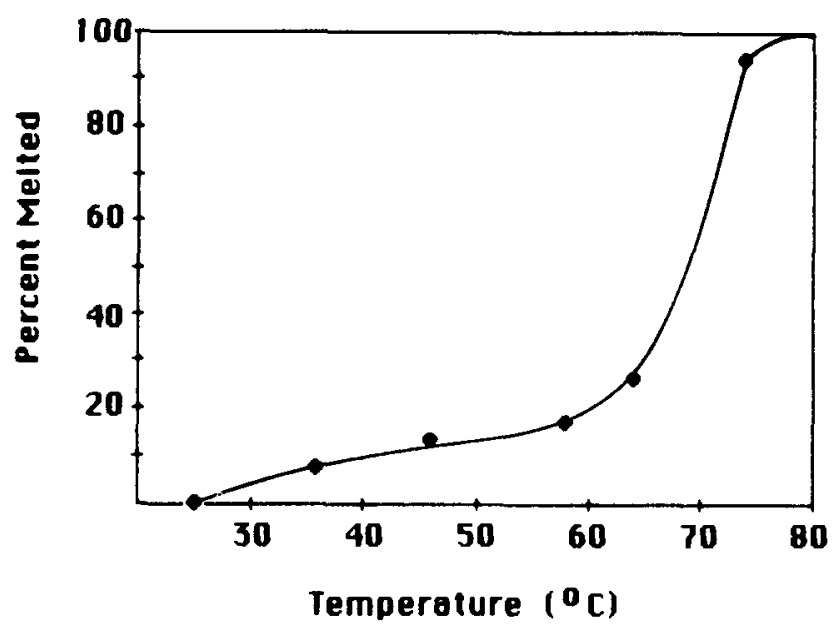

FIG. 5. In situ hybridization melting point (Tm) analysis of $5^{\prime}$ labeled $\alpha$-MSH oligomer in the intermediate lobe of the rat pituitary. Points indicate the percent signal lost following a 60 minute incubation at the indicated temperature. Tissue sections are initially hybridized and washed at $25^{\circ} \mathrm{C}$ as described in the text, and exposed to $\mathrm{X}$-ray film for 16 hours. Initial densitometry measurements are made of each section, and sets of four sections are incubated at the indicated temperatures, dried, and re-exposed to film for 16 hours. The loss of signal is determined by repeat densitometry. Extrapolation of the melting curve at the point of $50 \%$ melt indicates an experimental Tm value of $69^{\circ} \mathrm{C}$, in agreement with the theoretical value $\left(69^{\circ} \mathrm{C}\right)$.

cDNA can be "blocked" by excess message sense DNA).

(c) Multiple hybridization probes. Using adjacent sections, probes complementary to different regions of the same mRNA can be used to determine whether both hybridize to the same cells, providing additional evidence for the specificity of hybridization. When applied to the same section, the use of such probes should result in an enhanced cellular signal. Preliminary experiments in our laboratory with three different oligonucleotides (each a 30mer) specific for three different regions of the rat prodynorphin $\mathrm{mRNA}$ indicate that each demonstrates correct anatomical distribution within the hypothalamus. Use of these oligomers in concert should provide the amplification necessary for comparative visualization of this low abundance mRNA with that of AVP mRNA in same section and/or serial section analyses. If the probes are differentially labeled (e.g., with $\left[{ }^{3} \mathrm{H}\right]$ and biotin $[38,44,61]$ or $\left[{ }^{3} \mathrm{H}\right]$ and $\left[{ }^{35} \mathrm{~S}\right][22]$, colocalization of hybridization can be demonstrated within a single tissue section.

(d) Thermal stability of in situ hybrids. An important characteristic of a DNA-RNA hybrid is its mean thermal denaturation temperature; i.e., the $\mathrm{Tm}$, the temperature at which $50 \%$ of the hybrids dissociate (see Fig. 5). The value of Tm depends on factors such as \% G-C content, length, and base-pair mismatches $[6,8,9]$. Since base-pair mismatches reduce the thermal stability of hybrids, Tm analysis can be used to determine whether a labeled probe is hybridizing to the appropriate complementary sequence in situ $[31,64]$. Tm values obtained from in situ studies can be compared to those obtained from solution or solid phase hybridization studies of extracted RNA [31,64], and can be compared to calculated theoretical $\mathrm{Tm}$ values [31], using the formula $\mathrm{Tm}=16.6 \log [\mathrm{Na}]+(41 \times$ fraction $\mathrm{GC}$ base pairs $)+81.5-$ $1^{\circ} \mathrm{C} / 1 \%$ mismatch $-[300+(2000 \times[\mathrm{Na}]) /$ probe length $]$ (see $[6,8,9])$. For example, proopiomelanocortin mRNA is pres-

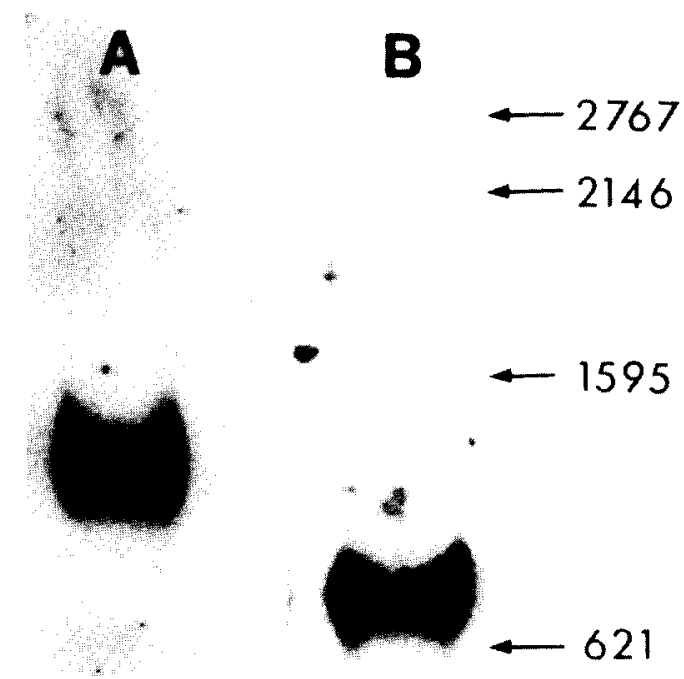

e.

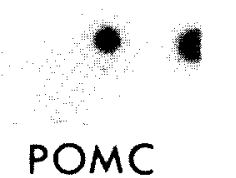

AVP

FIG. 6. Northern analysis of proopiomelanocortin and vasopressin mRNAs with oligonucleotides. Poly(A)RNA was isolated from 0.1 $\mathrm{mg}$ of total rat pituitary or hypothalamic RNA using oligo(dT)cellulose in a batch method, as described. The RNAs were denatured, electrophoresed, and transferred to nitrocellulose membranes as described in the text. The pituitary RNA (lane A) was probed with 5 '-end labeled $\alpha$-MSH oligomer, and the hypothalamic RNA (lane B) with the 5 '-end labeled AVP II oligomer. The molecular length markers along the side were made by mixing Acc J cut pBR322 with Acc I and Hind III cut pBR322.

ent in the intermediate but not posterior lobe of rat pituitary, so hybrids in the former should have an apparent Tm similar to the theoretical Tm, while mismatched "hybrids" in the latter, being less thermally stable, should have a much lower apparent $\mathrm{Tm}$. We obtained precisely this result using an oligonucleotide complementary to the $\alpha$-MSH coding region of proopiomelanocortin [36], indicating the usefulness of $\mathrm{Tm}$ analysis in discriminating specific and nonspecific hybridization in situ. Furthermore, addition of a homopolymer tail to the 3 '-end of the oligonucleotide in the terminal deoxynucleotidyl transferase labeling reaction does not significantly alter the hybridization properties ( $\mathrm{Tm}$ ) of the probe [38].

Finally, the $\mathrm{Tm}$ value for an oligonucleotide will indicate which temperature the signal for that specific hybridization is maximized compared to background. It is common to suggest a hybridization temperature of $\mathrm{Tm}-20^{\circ} \mathrm{C}$ as optimal, or at least as a good starting point. The optimal hybridization 
temperature of $45^{\circ} \mathrm{C}$ for the $\alpha$-MSH oligomer stemmed from the experimentally determined $\mathrm{Tm}$ of $69^{\circ} \mathrm{C}$ for the $\alpha-\mathrm{MSH}$ oligomer (Fig. 5).

(e) Northern analysis. Determination of specific mRNA size and abundance with the same oligonucleotide probe used in anatomical preparations provides an index of hybrididization specificity not realized in immunocytochemistry. Studies in our laboratory have indicated that intact mRNA of correct size can be isolated from formaldehyde-fixed tissue and quantitated by both dot-blot hybridization and Northern analyses [30,31]. Furthermore, quantitative Northern analysis is the method of choice for the corroboration of in situ hybridization detected mRNA level changes induced by development or physiological manipulations, as was demonstrated with vasopressin mRNA during salt-loading [59]. Due to the relatively low specific activities attainable with $\left[{ }^{32} \mathrm{P}\right]-k$ inased oligomers compared to either nicktranslated or M13-primed probes, satisfactory results are difficult to obtain with rare mRNAs; however, quantitative results with moderately abundant RNAs have proved informative. For example, rat vasopressin mRNA is readily detected in hypothalamic RNA using the AVP II 26mer oligonucleotide, and yet, when using any of three different 30 mer oligomers to rat dynorphin, which is a low abundance RNA $(<1 \%$ of AVP mRNA) present in the same tissue (and same cells), the results are negative. Either mRNA is readily detected with nick-translated probes, however.

Figure 6 illustrates the identification of proopiomelanocortin (POMC) mRNA in RNAs isolated from rat pituitary intermediate lobe with the $\alpha$-MSH $24 \mathrm{mer}$ (lane A) and of provasopressin (AVP/RNp 1) mRNA in rat hypothalamic RNA with the AVP II 26mer (lane B). The POMC mRNA exhibits an apparent molecular size of 1230 nucleotides and the AVP/RNp I mRNA a size of 740 nucleotides, both consistent with published values. Total cellular RNA can be isolated and analyzed by the Northern procedure as follows:

The RNA is extracted from frozen dissected tissues after a modification of Chirgwin [10]. The tissues are homogenized with tissue-glass homogenizers in $2.0 \mathrm{ml} / \mathrm{g}$ tissue of $6.0 \mathrm{M}$ guanidinium-isothiocyanate (Fluka), $25 \mathrm{mM}$ sodium citrate, $\mathrm{pH} 7.0,0.5 \%$ sodium sarkosyl, and $1.0 \mathrm{M} 2-\mathrm{mer}-$ captoethanol. The homogenates are incubated at $65^{\circ} \mathrm{C}$ for 10 minutes and centrifuged at $20,000 \mathrm{rpm}$ in a Sorvall SS-34 rotor. The supernatant is made $0.4 \mathrm{~g} \mathrm{CsCl} / \mathrm{ml}$ and layered over a $5.7 \mathrm{M} \mathrm{CsCl}, 0.1 \mathrm{M}$ EDT A, pH 7.5, cushion in a Beckman SW 50.1 Ti rotor polyallomer tube. Gradients are centrifuged for 14 hours at $20^{\circ} \mathrm{C}$ at $35,000 \mathrm{rpm}$. The supernatant is removed, the tube inverted and the walls dried. The RNA pellet is resuspended in $0.2 \mathrm{ml}$ of $0.1 \mathrm{M}$ Tris- $\mathrm{HCl}$, pH $7.3,12.5 \mathrm{mM}$ EDTA, $0.15 \mathrm{M} \mathrm{NaCl}, 0.2 \%$ SDS and 0.02 $\mathrm{mg} / \mathrm{ml}$ proteinase $\mathrm{K}$, and incubated at $37^{\circ} \mathrm{C}$ for $30 \mathrm{~min}$. The RNA is extracted with phenol/chloroform and ethanol precipitated from $0.3 \mathrm{M}$ sodium acetate, $\mathrm{pH} 5.7$.

For Northern analysis, the RNAs are adjusted to $50 \%$ formamide, $20 \mathrm{mM}$ morpholinepropanesulfonic acid (MOPS), pH 7.0, $5 \mathrm{mM}$ sodium acetate, $1 \mathrm{mM}$ EDTA and 2.2 $M$ formaldehyde. The RNA is denatured at $65^{\circ} \mathrm{C}$ for $10 \mathrm{~min}$ utes and fractionated on a $1.5 \%$ agarose gel containing $2.2 \mathrm{M}$ formaldehyde, $20 \mathrm{mM}$ MOPS, $\mathrm{pH} 7.0,5 \mathrm{mM}$ sodium acetate and $1 \mathrm{mM}$ EDTA. The RNAs are transferred to nitrocellulose membranes using passive transfer in 20X-SSC overnight [65] and hybridized as previously described $[25,67$, $68]$.

\section{PRESENT AND FUTURE DIRECTIONS}

At present, in situ hybridization histochemistry has two major applications of interest to peptide neurobiologists [20]. First, the combination of in situ hybridization histochemistry and immunocytochemistry permits the discrimination between a site of peptide biosynthesis (double-stained) and storage or uptake (peptide-positive only). For example, application of this technique has confirmed hypothalamus as a site of proopiomelanocortin biosynthesis, apart from pituitary, by demonstrating colocalization of both the mRNA and a precursor product, ACTH, in the same hypothalamic neurons [19]. The second major application is the study of changes in gene expression following physiological or pharmacological manipulations, e.g., the selective changes in proopiomelanocortin mRNA levels in anterior and intermediate lobe of pituitary, respectively, following glucocorticoid manipulations [20] and haloperidol administration [20, 31,38 ]. A related application is the study of alteration of gene expression during development $[28,58]$. Several groups of investigators are now using oligonucleotide probes to explore such questions $[13,36-38,66]$.

Further applications of in situ hybridization histochemistry will be aided by improvements in quantification, resolution, and sensitivity. Quantification, in particular, remains a challenging problem for a variety of reasons, including: (a) possible losses of RNA during fixation, (b) error due to absorption of $\beta$ particles, especially with $\left[{ }^{3} \mathrm{H}\right]$, and (c) necessity for controlling chemography, fading, background, emulsion thickness, linearity of emulsion response, and constancy of exposure and development conditions [16,24]. Some of these problems can be overcome by the careful use of appropriate standards, but such studies are as yet rare for in situ hy. bridiation.

Future developments with oligonucleotides may include: (a) the use of intron-exon probes to detect unprocessed hnRNA as an index of biosynthesis, (b) colocalization of two different mRNA species using pairs of probes labeled with $\left[{ }^{3} \mathrm{H}\right]$ or biotin $[38,44,61]$ or $\left[{ }^{3} \mathrm{H}\right]$ or $\left[{ }^{35} \mathrm{~S}\right][22]$ to discriminate each member of the pair, (c) detection of genetic disorders in patient tissue samples, and (d) with the advent of truly quantitative in situ hybridization and immunocytochemistry, the ability to correlate changes in gene expression and peptide levels in single cells under a variety of experimental conditions.

\section{ACKNOWLEDGEMENTS}

This work was supported by NIDA Grant DA02265 to Huda Akil, NIMH Grant MH39717 to SJW, NIMH Training Grant MH15794 to MEL and NIADDK Grant P30AM34933 to SJW and TGS. The authors wish to thank Ms. Adele Henry for manuscript preparation, Ms. Sharon Burke and Mr. Guilio Baldrighi for technical assistance, and Drs. Rene Arentzen and Leonard G. Davis (E. I. DuPont de Nemours and Co.) for providing the $\alpha$-MSH synthetic oligonucleotide.

\section{REFERENCES}

1. Agarwal, K. L., J. Brunstedt and B. E. Noyes. A general method for detection and characterization of an mRNA using an oligonucleotide probe. $J$ Biol Chem 256: 1023-1028, 1981.
2. Alton, T. H. and H. F. Lodish. Translational control of protein synthesis during the early stages of differentiation of the slime mold Dictyostelium discoidium. Cell 12: 301-310, 1977. 
3. Amara, S. G., V. Jonas, M. G. Rosenfeld, E. S. Ong and R. M. Evans. Alternative RNA processing in calcitonin gene expression generates mRNAs encoding different polypeptide products. Nature 298: 240-244. 1982.

4. Beltz, W. R. and K. J. O'Brien. End labeling of DNA restriction fragments using $\left.{ }^{35} \mathrm{~S}\right]$ adenosine $5^{\prime}$-(gamma-thio) triphosphate followed by mercury affinity chromatography (methods flyer from New England Nuclear) or Am Soc Biol Chem Abstr, 1981.

5. Bollum, F. J. Terminal deoxynucleotidyl transferase. In: The Enzymes, vol 10, edited by P. D. Boyer. New York: Academic Press, 1974

6. Bonner, T. I., D. J. Brenner, B. R. Neufeld and R. J. Britten. Reduction in the rate of DNA reassociation by sequence divergence. $J$ Mol Biol 81: 123-135, 1973.

7. Brahic, M. and A. T. Haase. Detection of viral sequences of low reiteration frequency by in situ hybridization. Proc Natl Acad Sci USA 75: 6125-6129, 1978.

8. Britten, R. J., D. E. Graham and B. R. Neufeld. DNA sequence analysis by reassociation. In: Methods in Enzymology, vol 29. edited by L. Grossman and K. Moldave. New York: Academic Press, 1974, pp. 363-418.

9. Cantor, C. R. and P. R. Schimmel. Biophysical Chemistry. San Francisco, CA: W. H. Freeman, 1982.

10. Chirgwin, J. M., A. E. Przybyla, R. J. MacDonald and W. J. Rutter. Isolation of biologically active ribonucleic acid from sources enriched in ribonuclease. Biochemistry 18: 5294-5299, 1979.

11. Civelli, O., J. Douglass and E. Herbert. Sequence and expression of the rat prodynorphin gene. Proc Natl Acad Sci USA. in press.

12. Comb. M., P. H. Seeburg, J. Adelman, L. Eiden and E. Herbert. Primary structure of the human Met- and Leu-enkephalin precursor and its mRNA. Nature 295: 663-666, 1982.

13. Davis, L. G., B. Wolfson, R. Arentzen, R. W. Manning, G. A Higgins, Y. Lin and F. Baldino, Jr. In situ hybridization of neuropeptide mRNA within the rat hypothalamus with radiolabeled synthetic oligonucleotide probes. Soc Nomrosit Abstr 10: 359, 1984.

14. Deng, G. and R. Wu. An improved procedure for utilizing terminal transferase to add homopolymers to the $3^{\prime}$ termini of DNA. Nucleic Acids Res 9: 4173-4188, 1981.

15. DeNoto, J. M., D. D. More and H. M. Goodman. Human growth hormone DNA sequence and mRNA structure: Possible alternate splicing. Nucleic Acids Re's 9: 3719, 1981.

16. Dormer, P. Quantitative autoradiography at the cellular level. In: Methods in Molecular Biology. London: Springer-Verlag. 1973.

17. Erichson, B. W. and R. B. Merrifield. In: The Proteins, vol 2, edited by $\mathrm{H}$. Neurath, R. L. Hill and C. L. Boeder. New York: Academic Press, 1976, pp. 255-527.

18. Gait, M. J., H. W. D. Mattes, M. Singh, B. S. Sproat and R. C. Titmas. Rapid synthesis of oligonucleotides. VII. Solid phase synthesis of oligodeoxynucleotides by a continuous flow phosphotriester method on a kieselguhr-polyamide support. Nucleic Acids Res 10: 6243-6254, 1982.

19. Gee, C. E.. C. L. Chen, J. L. Roberts, R. Thompson and S. J. Watson. Identification of proopiomelanocortin neurons in rat hypothalamus by in situ cDNA-mRNA hybridization. Nature 306: $374-376,1983$.

20. Gee, C. E. and J. L. Roberts. Laboratory methods for in sitt hybridization histochemistry: a technique for the study of gene expression in single cells. DNA 2: 155-161, 1983.

21. Griffin, W. S. T.. M. Alejos, G. Nilaver and M. R. Morrison. Brain protein and messenger RNA identification in the same cell. Brain Res Bull 10: 597-601, 1983.

22. Haase, A. T., D. Walker, L. Stowring, P. Ventura, A. Geballe, H. Blum, M. Brahic. R. Goldberg and K. O'Brien. Detection of two viral genomes in single cells by double-label hybridization in situ and color microradioautography. Science 227: 189-192, 1985.
23. Hagenbuchle, O., M. Tosi, U. Schibler, R. Bovey, P. K. Wellauer and R. A. Young. Mouse liver and salivary gland a-amylase mRNAs differ only in 5' non-translated sequences. Nature 289: 643-646, 1981.

24. Herkenham, M. Levels of quantitative analysis of receptor autoradiography: technical and theoretical issues. NIDA Res Monogr, in press.

25. Itakura, K.. J. J. Rossi and R. B. Wallace. Synthesis and use of synthetic oligonucleotides. Annu Rev Biochem 53: 323-356. 1984.

26. Ito, H., Y. Ike, S. Ikuta and K. Itakura. Solid phase synthesis of polynucleotides, VI. Further studies on polystyrene copolymers for the solid support. Nucleic Acids Re's 10: 1755-1769. 1982.

27. Jacobs, J. W.. R. H. Goodman, W. W. Chin, P. C. Dee, J. F. Habener, N. H. Bell and J. T. Potts, Jr. Calcitonin messenger RNA encodes multiple polypeptides in a single precursor. Si $i$ ence 213: 457-459, 1981.

28. John, H. A., M. Patrinau-Georgoulas and K. W. Jones. Detection of myosin heavy chain mRNA during myogenesis in tissue culture by in vitro and in situ hybridization. (c/l 12: 501-508. 1977

29. Kakidani, H., Y, Furutani, H. Takahashi, M. Noda, Y Morimoto, T. Hirose, M. Asai, S. Inayama, S. Nakanishi and S. Numa. Cloning and sequence analysis of CDNA for porcine beta-neo-endorphin/dynorphin precursor. Nature 298: 245-249. 1982.

30. Kelsey. J. E., S. J. Watson and H. Akil. Changes in pituitary mRNA levels. Soc Nerurosci Abstr 10: $359,1984$.

31. Kelsey, J. E., S. J. Watson, S. Burke, H. Akil and J. L. Roberts. Characterization of proopiomelanocortin mRNA de tected by in situ hybridization. I Ne'urosci, in press

32. Khorana, H. G. and J. P. Vizsolyi. Studies on polynucleotides. VIII. Experiments on the polymerization of mononucleotides. Improved preparation and separation of linear thymidine polynucleotides. Synthesis of corresponding members termi nated in deoxycytidine residues. J Am Chem Sor 83: 675-685. 1961.

33. Land, H., M. Grez, S. Ruppert, H. Schmale, M. Rehbein, D. Richter and G. Schutz. Deduced amino acid sequence from the bovine oxytocin-neurophysin I precursor cDNA. Nature 302: 342-344. 1983.

34. Land, H., G. Schutz, H. Schmale and D. Richter. Nucleotide sequence of cloned cDNA encoding bovine arginine vasopressin-neurophysin II precursor. Nature 295: 298-303. 1982 .

35. Lewis, U. L., L. F. Bonewald and L. J. Lewis. The 20,000dalton variant of human growth hormone: localization of the amino acid deletion. Biochem Biophys Res Commun 92: 511, 1980.

36. Lewis, M. E., S. Burke, T. G. Sherman, R. Arentzen and S. J. Watson. In situ hybridization using a 3 ' terminal transferase labeled synthetic oligonucleotide probe complementary to the alpha-MSH coding region of proopiomelanocortin mRNA. Sor Neurosci Abstr 10: 358.1984

37. Lewis, M. E., H. Khachaturian, M. K. H. Schafer and S. J. Watson. Anatomical approaches to the study of neuropeptides and related mRNA in CNS. In: Neuropeptides in Neurological Diserse. ARNMD, vol 64, edited by J. B. Martin. New York: Raven Press, in press.

38. Lewis, M. E.. T. G. Sherman, S. Burke, H. Akil. L. G. Davis, R. Arentzen and $S$. J. Watson. Detection of proopiomelanocortin mRNA by in situ hybridization with an oligodeoxynucleotide probe. In preparation.

39. Lynn, D. A., L. M. Angerer, A. M. Bruskin, W. H. Klein and R. C. Angerer. Localization of a family of mRNAs in a single cell type and its precursors in sea urchin embryos. Pror Natl Acad Sci USA 80: 2656-2660, 1983.

40. Maniatis. T.. E. F. Fritsch and J. Sambrook. Molecular Cloming. New York: Cold Spring Harbor Laboratory, 1982. 
41. Mason, A. J., B. A. Evans, D. R. Cox, J. Shine and R. I. Richards. Structure of mouse kallikrein gene family suggests a role in specific processing of biologically active peptides. $\mathrm{Na}$ ture 303: $300,1983$.

42. Matteucci, M. D. and M. H. Caruthers. Synthesis of deoxynucleotides on a polymer support. J Am Chem $S_{0}(\mathrm{C}$ 103: 3185-3191. 1981.

43. Maxam, A. M. and W. Gilbert. Sequencing end labeled DNA with base-specific chemical cleavages. In: Methods in Enaymology, vol 65, edited by L. Grossman and K. Moldave. New York: Academic Press, 1980, pp. 499-560.

44. Murasugi, A. and R. B. Wallace. Biotin-labeled oligonucleotides: enzymatic synthesis and use as hybridization probes. DNA 3: 14-17, 1984

45. Nawa, H., T. Hirose, H. Takashima, S. Inayama and S. Nakanishi. Nucleotide sequences of cloned cDNAs for two types of bovine brain substance P precursor. Nature 306: 32-36, 1983.

46. Nawa, H., N. Kitamura, T. Hirose, M. Asai, S. Inayama and S. Nakanishi. Primary structures of bovine liver low molecular weight kininogen precursors and their two mRNAs. Proc Natl Accad Sci USA 80: 90-94, 1983.

47. Nawa. H.. H. Kotani and S. Nakanishi. Tissue-specific generation of two preprotachykinin mRNAs from one gene by alternative RNA splicing. Nature 312: 729-734, 1984.

48. Noda, M.. Y. Furutani, H. Takahashi, M. Toyasato, T. Hirose, S. Inayama, S. Nakanishi and S. Numa. Cloning and sequence analysis of cDNA for bovine adrenal preproenkephalin. Nature 295: 202-208, 1982.

49. Noyes, B. E., M. Mevarech, R. Stein and K. L. Agarwal. Detection and partial sequence analysis of gastrin mRNA using an oligonucleotide probe. Proc Natl Acad Sci USA 76: 1770-1774, 1979.

50. Oates, E. and E. Herbert. 5'-Sequence of porcine and rat proopiomelanocortin mRNA. J Biol Chem 259: 7421-7425, 1984.

51. Palmiter, R. D. Regulation of protein synthesis in chick oviduct. I Biol Che'm 247: 6450-6461, 1972.

52. Palmiter, R. D. Ovalbumin messenger ribonucleic acid translation. I Biol Chem 248: 2095-2106, 1973

53. Pochet, R., H. Brocas, G. Vassart, G. Toubeau, H. Seo, S Refetoff, J. E. Dumont and J. L. Pasteels. Radioautographic localization of prolactin messenger RNA on histological sections by in situ hybricization. Brain Res 211: 433-438, 1981.

54. Richter, K., E. Kawashina, R. Egger and G. Kreil. Biosynthesis of thyrotropin releasing hormone in the skin of Xenopus lacvis: partial sequence of the precursor deduced from cloned cDNA The EMBO J 3: 617-621. 1984

55. Rushow, K. Sequence analysis of oligonucleotides by chemical modification. Focus 5: 1-4, 1983. (Bethesda Research Labs, Bethesda, MD).

56. Saber, M. A.. M. A. Zern and D. A. Shafritz. Use of in situ hybridization to identify collagen and albumin mRNAs in isolated mouse hepatocytes. Proc Nall Acad Sci USA 80: 40174020,1983
57. Sanger, F., A. R. Donelson, H. Coulson, H. Kossel and D. Fischer. Use of DNA polymerase I primed by a synthetic oligonucleotide to determine a nucleotide sequence in phage $\mathrm{fl}$ DNA. Proc Natl Acad Sci USA 70: 1209-1213, 1973.

58. Scheller, R. H., R. Kaldany, A. Kreiner, C. Mahon, R. Nambu, M Schaefer and R. Taussig. Neuropeptides: mediators of behavior in aplysia. Science 225: 1300-1308, 1984.

59. Sherman, T. G., H. Akil and S. J. Watson. Vasopressin mRNA expression: A northern and in situ hybridization analysis. In: Vasopressin. edited by R. Schrier. New York: Raven Press. 1985 , in press.

60. Sherman, T. G., S. J. Watson, E. Herbert and H. Akil. The co-expression of dynorphin and vasopressin: an in situ hybridization and dot-blot analysis. Soc Neurosci Abstr 10: 358, 1984.

61. Singer, R. H. and D. C. Ward. Actin gene expression visualized in chicken muscle tissue culture by using in situ hybridization with a biotinated nucleotide analog. Proc Natl Acad $S \subset i$ USA 79: $7331-7335,1982$.

62. Smith, H. O. Recovery of DNA from gels. In: Methods in Enzymology, vol 65. New York: Academic Press, 1980, pp. 371-380.

63. Stewert, J. W. and F. Sherman. Yeast frameshift mutations identified by sequence changes in iso-l-cytochrome $c$. In: Molecular and Environmental Aspects of Mutagenesis, edited by L. Prakesh, F. Sherman. M. W. Miller, C. W. Lawrence and H. W. Tabor. Springfield, IL: Thomas, 1974. pp. 102-107.

64. Szabo. P., R. Elder, D. M. Steffensen and O. C. Uhlenbeck. Quantitative in situ hybridization of ribosomal RNA species to polytene chromosomes of Drosophila melanogaster. J Mol Biol 115: 539-563, 1977.

65. Thomas, P. S. Hybridization of denatured RNA and small DNA fragments transferred to nitrocellulose. Proc Natl Acad Sri USA 77: 5201-5205. 1980.

66. Uhl. G. R., G. O. Hackeney, H. Zing, G. Heinrich and J. F. Habener. Supraoptic vasopressin and dynorphin mRNA visualized by in situ hybridization: advantages of synthetic oligonucleotide probes. Soc Neurosci Abstr 10: 375, 1984

67. Wallace. R. B., M. J. Johnson, T. Hirose, T. Miyake, E. Hawashima and $\mathrm{K}$. Itakura. The use of synthetic oligonucleotides as hybridization probes. Nucleic Acids Res 9: 879-895, 1981.

68. Wallace, R. B., J. Shaffer, R. F. Murphy, J. Bonner. T. Hirose and $\mathrm{K}$. Itakura. Hybridization of synthetic oligodeoxyribonucleotides to phi-X 174 DNA: the effect of single base pair mismatch. Nucleic Acids Res 6: 3543-3557, 1979.

69. Watson. S. J. and H. Akil. Immunocytochemistry of peptides. In: Current Methods in Cellular Neurobiology, Vol l: Anatomical Techniques, edited by J. L. Barker and J. E. McKelvy. New York: John Wiley and Sons, 1983. pp. 111-131. 